\title{
The Role of Digital Marketing in Enlarging Islamic Banking Market Share in Indonesia
}

\author{
Slamet Hidayat ${ }^{1}$, Nurwahidin ${ }^{2}$, Nurul Huda ${ }^{3}$ \\ \{slamhidayat1@gmail.com ${ }^{1}$, nurwahidin@ui.ac.id ${ }^{2}$, pakhuda@yahoo.com ${ }^{3}$ \} \\ 1,2 Universitas Indonesia, Jl. Salemba Raya No. 4, Jakarta Pusat, DKI Jakarta, Indonesia, \\ ${ }^{3}$ Universitas YARSI, Jl. Letjend Suprapto No.1, Cempaka Putih, Jakarta Pusat
}

\begin{abstract}
This low market share of Islamic banking is influenced by the low level of literacy and inclusion of the community towards Islamic banking financial products and services. For this reason, some efforts and marketing strategies are needed to build massive awareness. Digital marketing as a marketing approach can be adopted in promoting the Islamic banking products and services. This study uses a mixture of qualitative and quantitative approaches to analyze the digital marketing roles from the experts and practitioners. Interviews with experts and practitioners were conducted, survey questionnaires as research instruments were distributed to informants. The DelphiAnalytic Network Process method is used for data analysis, and Super Decisions software as data processing tools. The results showed that to increase literacy, inclusion and enlarge market share of Islamic banking products and services, digital marketing plays role in building public trust, supporting the traditional marketing, developing digital campaigns and mapping target markets.
\end{abstract}

Keywords: Islamic banking, digital marketing, market share, literacy

\section{Introduction}

Market share is very positively related to profitability and sustainability (business continuity) of an industry, and this most often occurs in the industrial world that is experiencing a growth [1], [2]. In relation to the Islamic financial industry in Indonesia, market share is one indicator of the relative position of the Islamic financial industry in the competition of national financial industry. The higher market share reflects the higher strength of the Islamic financial industry in the national financial industry market competition. The level of public understanding of Islamic financial products and services is a very important factor in driving the development of Islamic finance in Indonesia. The utilization of the Islamic financial products and services is strongly influenced by the level of public understanding of the functions, types and characteristics of the Islamic financial product and service [3].

Based on the results of a financial literacy and inclusion survey conducted by the Otoritas Jasa Keuangan (OJK) in 2016, it shows that the level of literacy (understanding) and the level of inclusion (utilization) of the community regarding Islamic financial products and services is still low. The low index of literacy and Islamic financial inclusion is affecting the market share of the Islamic financial industry. According to data released by the Otoritas Jasa Keuangan (OJK), in June 2018 the global Islamic financial industry market share reached $8.47 \%$ with a breakdown of the Islamic Banking market share of 5.70\%, IKNB (Non-Bank Financial Industry) 
of $4.69 \%$ and the Islamic Capital Market by $15.28 \%$ [4]. In particular, despite an increase in the market share of the Islamic banking industry in Indonesia from previous years, the market share of only $5.7 \%$ is still felt very small if we compare it with the majority of Indonesia's population who are Muslim. This condition is reinforced and aligned by a research conducted by Ahmad and Haron (2002) in Malaysia, stating that in general Islamic banking product and service providers have not provided adequate literacy that can educate customers and market towards their products and services [5]. The lack of literacy and marketing (promotion) efforts among Islamic banking service providers is a major factor that contributes to the low market share of the Islamic banking [5]. Therefore, some specific efforts and actions on marketing are needed to increase public literacy and inclusion on a large scale. In this current digital era, the critical needs of building massive awareness, knowledge and interest of the community towards Islamic banking products and services can be done by the new marketing approach called digital marketing.

\section{Literature Review}

\subsection{Overview}

The Digital Marketing Institute defines digital marketing as "the use of digital technology to create integrated, directed and measurable communications that help to obtain and retain customers while building deeper relationships with them" [6]. Simply put, digital marketing can be defined as "an effort to achieve marketing objectives through the application of technology and digital media" [7]. This technology and digital media included the internet, desktop devices, cellular phones (cellphones, smartphones), tablets and other digital platforms. Meanwhile, WSI defines digital marketing as the practice of promoting products and services in innovative ways, using data-based distribution channels (databases) to reach prospective consumers in a timely, personally relevant and cost-effective manner [8]. Digital marketing provides an important 'bridge' to the relationship between customer perspectives that are often 'in touch' with the digital world, and digital conversation interfaces that companies use to provide relevant contents for customers [6].

The main difference between digital marketing and traditional marketing is that digital marketing uses digital technology that can be measured inherently, enables targeted conversations, and facilitates the creation of relationships between customers and companies, whereas traditional marketing is more oriented towards mass communication [9]. Digital marketing utilizes the unique and powerful characteristics of interactive media with addressable characteristics, meaning that each user can be identified and targeted separately to enable twoway interactions, services can be tailored for each individual customer and purchases can be made and influenced online [10]. Digital channels can be addressed, allowing marketers to have a continuous personal dialogue, two-way communication with each consumer. This dialogue utilizes data from each customer interaction to inform the next data or information, just like a neural network in the human brain. In addition, marketers use real-time consumer behavior information and get feedback from consumers directly to improve and optimize interactions [11]. Information and literacy obtained from social media (and other digital platforms) is what gives influence, especially on consumer decision making [12].

The basic concept in digital marketing is based on an approach called "inbound marketing", which is a method or technique of promoting business through blogs, podcasts, videos, eBooks, 
e-newspapers, whitepapers, SEO (Search Engine Optimization), products physical marketing through social media, and other content marketing methods that work to attract customers through different stages of the usual approach to traditional marketing. Inbound marketing allows an open and "smart" communication to customers by shifting their attention to the company's products or services and creating personal relationships with them by promoting content that is tailored to their needs [13].

By taking advantage of some opportunities through the digital channels or digital media, such as social media (Facebook, Instagram, LinkedIn, Twitter, etc.), has proven to be the key of successful promotion and marketing of a product or service [14]. Digital marketing has become the most innovative phenomenon in the field of marketing [15], and it is important to be applied in all businesses, as well as it is possible to apply it into the marketing of Islamic banking industry in Indonesia. Digital marketing as an innovation and new approach in the world of marketing, making it the most disruptive marketing method, which combines traditional marketing with the use of media and digital technology (internet, website, social media, mobile devices, email, and so on). Digital marketing can play a role as an actuator, or as a liaison (mediator) to improve literacy and inclusion of Islamic banking financial products and services by implementing specific strategies. Some digital marketing roles and strategies can be adopted and implemented in the marketing of Islamic banking products and services, of course, by analyzing and considering the suitability or contextual factors of the roles and strategies with the situation, conditions and problems encountered.

This research refers to the Diffusion of Innovation Theory (DOI), which is a process of spreading uptake of ideas or innovations that are communicated through certain channels in an effort to change a society that occurs continuously from one place to another, from a period of time to the next period, from one particular field to another within a group of members of a social system [16]. According to Wunderlich, et al. (2014), the DOI theory describes a process in which new technologies or innovations are disseminated or communicated to all layers of culture or society, underlining the extent to which the role of innovation in initiating a change [17]. In other words, DOI theory seeks to interpret changes that occur within the society in the term of the development of innovations, how these innovations are communicated, and the extent to which they provide changes in the community or culture [18]. This applies to every innovations, including the adoption of digital marketing approach in the most existing businesses, with the aim of expanding the market base through digital environments and digital ecosystems.

According to Kung (2008) stated that the changes and innovations in the field of technology and consumer behavior have always been the main drivers of strategic changes in relation to the use of marketing media [19]. The adoption of digital marketing into the Islamic banking industry, moreover as a new approach in the field of marketing of Islamic banking products and services, must be through the identification stage of the role of digital marketing. This stage requires initial knowledge, which according to Rogers (1995) is the knowledge about unit characteristics (socio-economic conditions, individual variables, and communication behavior), as well as the characteristics of innovation itself (relative advantage, compatibility, complexity, triability, and observability) [16].

\subsection{Critical Evaluation}

Recent research by Handida and Sholeh (2018) shows that the level of knowledge and literacy of Islamic finance has a positive and significant impact on people's decisions to use Islamic banking products and services in the Daerah Istimewa of Yogyakarta (DIY) [20]. This 
was also reinforced by other studies conducted by Sardiana (2016) and Sardiana (2018), who stated that there was a significant influence between Islamic financial literacy and people's preferences to use Islamic banking services [21], [22]. This also means that the higher the level of sharia financial literacy in the community, the probability of using sharia financial products and banking services will also be higher. Meanwhile, according to research conducted by Hakim, Bhatti and Al-Jubari (2011), shows that the sharia banking industry is faced with challenges to convince customers about the benefits of the product, and conduct education about the availability of a number of sharia banking financing products that are more profitable than the credit facilities provided by conventional banks, when promoting financial products and services to the public [23]. For this reason, some efforts are needed to improve public literacy towards Islamic banking financial products and services, by carrying out appropriate and optimal marketing strategies. In addition, the Islamic banking industry must also launch a massive campaign to build public awareness specifically on a large scale. The campaign must focus on efforts to explain the features and benefits of Islamic financial products and eliminate the perception of complexity and uncertainty about Islamic financial products and services [23].

Some previous studies can be used as reference in explaining the role of digital marketing is Stephen (2016) research on the role of digital and social media marketing on consumer behavior, explaining that the process of learning (educating) someone from other people (close friends, friends, public figures) in a digital environment can influence individual decisions in that environment and the conclusions they make about new information or something they get from people [12]. A study conducted by Davis (2017), found that digital marketing is a key component for business continuity. In the environment that has good understanding about technology as it is today, most businesses have sought to exploit marketing through digital means as a major contributor to sustainability of their business [24]. Research by Mayilvaganan and Karthikeyan (2012) explains that marketing in banking services shows different features. Customer loyalty to a brand (called brand loyalty) is the main thing that is the focus of the banking service business. Personal selling plays an important role in promoting and marketing the banking services [25]. Gironda and Korgaonkar (2014) also stated that one of the roles of digital marketing is to provide publications and information about products through digital assets such as websites and social media channels [26]. While Wymbs (2011) provides an overview of the role of digital marketing, which is to build 'digital trust' to the community and prospective customers by building credible digital assets [6].

Digital marketing has successfully been implemented in the 'conventional' marketing manners. But, the condition is not likely as the same as in the 'Islamic' banking product and service. The importance of digital marketing still has not properly adopted and implemented in the marketing of the Islamic banking product and services. This condition can be confirmed by the lack of previous studies in Islamic banking which are concerning about digital marketing. Both of literature references and the previous studies about digital marketing towards the Islamic banking product and services marketing are still very limited. Therefore, this study was conducted to study and analyze the role of digital marketing in the Islamic banking products and services marketing. The ultimate goal is to enlarge the market share of Islamic banking products and services, especially in Indonesia. So that the research question in this study is: "What are the role of digital marketing in enlarging the market share of Islamic banking product and service in Indonesia?" 


\section{Methodology}

This research was conducted using a mixture both qualitative and quantitative approach, using primary data obtained by conducting in-depth interviews with experts and practitioners of digital marketing and sharia banking practitioners to understand the problem comprehensively. The informants consisted of five practitioners and digital marketing experts, one informan from academic as well as digital marketing practitioners, and a practitioner from Islamic banking who has responsibility and experience on the digital marketing field. This research is also supported by secondary data sourced from literature studies and previous studies. This study uses the Delphi-Analytic Network Process (ANP) data analysis method, which is a combination of the Analytic Network Process (ANP) method and the Delphi approach. The Diffusion of Innovation (DOI) theory and the AIDA model (Attention, Interest, Desire, and Action) serve as the conceptual framework of the analysis. While Super Decisions software is used as data processing tools.

Diffusion of Innovation Theory (DOI theory) states that the process of spreading uptake of ideas or new things (innovation) is communicated through certain channels in an effort to change a society that occurs continuously from one place to another, from one period to the next, from one particular field to another, and to a group of members of a social system or community [16]. While the AIDA model is used in the selection of relevant and optimal digital marketing roles to be applied in marketing Islamic banking financial products and services, so that it is expected to increase literacy, inclusion and enlarge market share. The AIDA model has been widely used in various marketing activities such as promotion, advertising, sponsorship, and business activities. In 1898, E. St. Elmo Lewis proposes a communication theory called the AIDA model, an acronym that refers to Attention, Interest, Desire and Action. This theory was developed based on research in the life insurance industry that illustrates the four cognitive phases that a person experiences after receiving a new idea or a new product being purchased [27]. The AIDA model has become a basic model in marketing that is widely applied in regulating advertising and promotion resulting from customer perception.

This study uses a combined data analysis method from the Analytic Network Process (ANP) method with the Delphi approach, because the ANP framework does not fully support the decision making process in a group of informants who come from their respective background expertise and competencies. Due to this decision-making process involves a group of contributors with diverse views and preferences, a sense of responsibility and consensus among contributors is an important element in ensuring the success of the whole process. Therefore the incorporation of the Delphi technique within the ANP framework, can facilitate the strong involvement of all contributors / informants in the process, resulting in unanimity among them [28]. The Delphi method is a structured communication technique, which was originally developed as an interactive and systematic forecasting method that relies on panels consisting of experts who are competent in their respective fields [29].

The in depth-interviews were conducted with informants (experts) with a number of requirements for expertise, experience and knowledge in the field of digital marketing. The aim is to increase literacy and inclusion of Islamic banking products and services and increase market share. Furthermore, the data is arranged and classified into AIDA criteria (Attention, Interest, Desire and Action). The entire list of digital marketing roles are then transformed into the Delphi questionnaire. Each informant was asked to fill out the questionnaire with the aim of choosing three alternative of "digital marketing roles" with the best ranking and align with the convergence requirements of each of the Attention, Interest, Desire and Action criteria. 
After the Delphi questionnaire was filled out by the informants in the evaluation panel, the results were obtained which were then arranged into tabular form. The table illustrates the evaluation and withdrawal of opinions and consensus from experts on the role of digital marketing to increase literacy, inclusion and enlarge the market share of Islamic banking in Indonesia. Evaluation of each alternative or element of each criterion of the AIDA model is based on calculating the highest mean (mean), as well as calculating convergence through the Standard Deviation and Interquartile Range (IR) values. Evaluation to express convergence or consensus on all instruments is when the standard deviation is $<1.5$ and the interquartile range $<2.5$. If one of them, both the standard deviation and interquartile range are not $<1.5$ and $<2.5$, then the instrument is declared not convergent or not agreed [30].

This study also combines the Delphi approach and data analysis techniques with the Analytic Network Process (ANP) method. This ANP technique is used to determine the best priority of the various alternatives of "the role of digital marketing". This is explained in Figure 1. The Analytic Network Process (ANP) is a mathematical theory that allows one to deal systematically with dependency and feedback and which can capture and combine tangible and intangible factors using a comparison scale [31]. The ANP is also a method used to handle complex decision making and involves dependence and feedback that is analyzed in the context of benefits, opportunities, costs, and risks. This has been applied literally into many cases, both real and hypothetical [32].

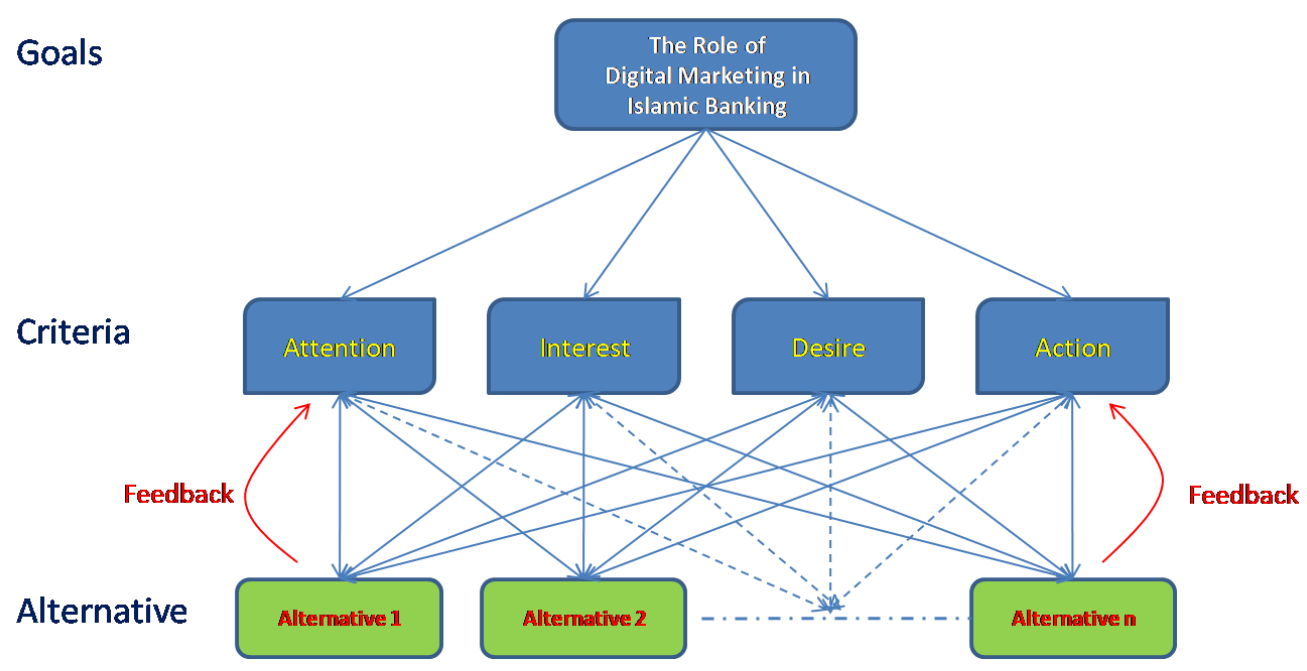

Fig. 1. Data Analysis in ANP Framework

Source: Saaty (2013) with adaptation (2019)

In sequence, this study can be explained into the research flowchart in Figure 2. The Delphi-ANP method used in this study consists of two Delphi stages, which are combined with the ANP procedure to produce eight steps of research. The Delphi technique is used in two stages, namely Phase I in determining evaluation criteria, and Phase II in forming and reviewing problems and criteria (elements) of the problem. The data analysis is then continued by using the ANP method to determine priorities and the best alternatives. The combination of Delphi 
approach and the ANP method forms eight steps of this study. Those eight steps are simply described as follow:
a) Problem formulation and factor identification;
b) Form an evaluation panel;
c) Determine evaluation criteria;
d) Structuring the problem into network model;
e) Elements rating;
f) Analysis of valuation weights;
g) Rating approval;
h) Selection of the best alternative.

The complete research flowchart is shown as below: 


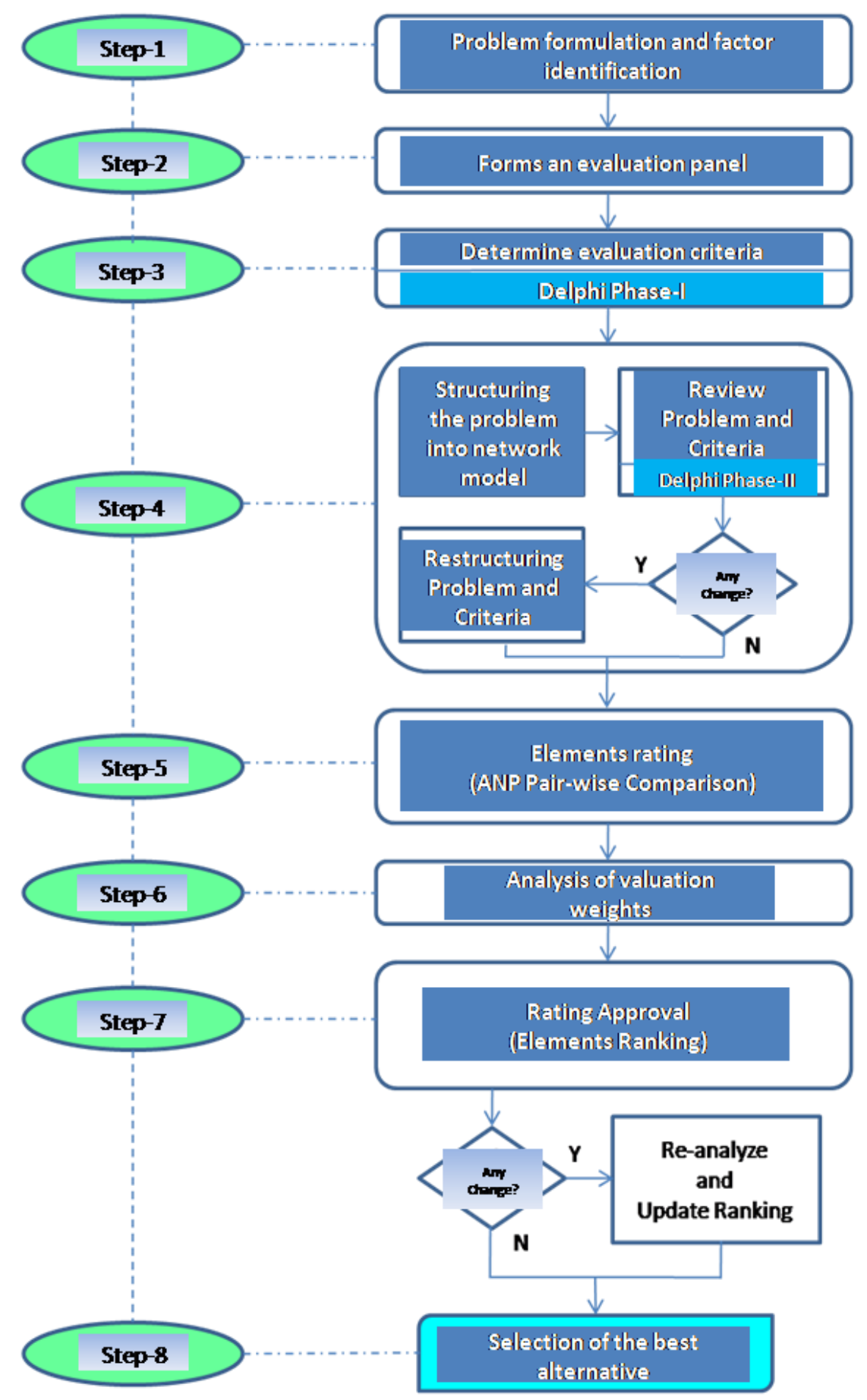

Fig. 2. Research Flowchart

Source: Ngeru, Bardhan, dan Pitts Jr. (2011) with adaptation (2019) 


\section{Results and Discussion}

Building the community and public literacy on a large scale can be done by optimizing technology that dominates all lines of life in society, namely digital technology. The development of internet technology and digital media has had a significant influence on almost all aspects of life, one of which is in the economic field. Based on the survey results of the Indonesian Internet Service Users Association (APJII) in 2017, the number of internet users in Indonesia reached 143.26 million people $(54.62 \%$ of the total population of Indonesia) and always experienced significant growth from year to year [33]. The survey also shows that the use of the internet for economic activities, the most common is the activity of finding information about prices (45.14\%), helping jobs (41.04\%), buying information (37.82\%), buying online (32.19) \%), looking for work (26.19\%), banking transactions $(17.04 \%)$ and selling online $(16.83 \%)$.

From a consumer perspective, the use of communication technology, internet and other digital media offers a number of benefits, including efficiency, convenience, richer and participatory information, wider product choices, competitive prices, cost reduction, and product diversity [34]. Even though we live in an interactive online world, one of them is the emergence of social media, people's decision to buy and consume a product, or use a service (service) is influenced by public awareness of the existence of a product, so that it can cause public interest. The interest towards a product based on information obtained, expressing a desire to own or use a product because the product or service is in accordance with their needs, desires, and interests, and take action to make a decision to buy or other relevant actions [27].

Based on ANP data processing results from the Super Decisions software for AIDA model show that in general, the main priority of the role of digital marketing to increase literacy, inclusion and enlarge the market share of Islamic banking is how digital marketing plays a role in increasing public Interest. The Interest is a phase of AIDA model (Attention - Interest Desire - Action) that describing four cognitive phases of person experiences after receiving information comes from advertising and promotional media and other marketing communications about a new products or services. The evaluation on the priority criteria of AIDA showed that Interest got the highest priority weight of 0.2995 and a Rater Agreement of 0.557. The Rater Agreement value of 0.557 or $55.7 \%$ shows the variation of the answers of the respondents regarding the AIDA criteria, with the level of agreement and the suitability of the answers among the informants is quite strong (moderate to strong agreement). These result is explained in Graph 1. 


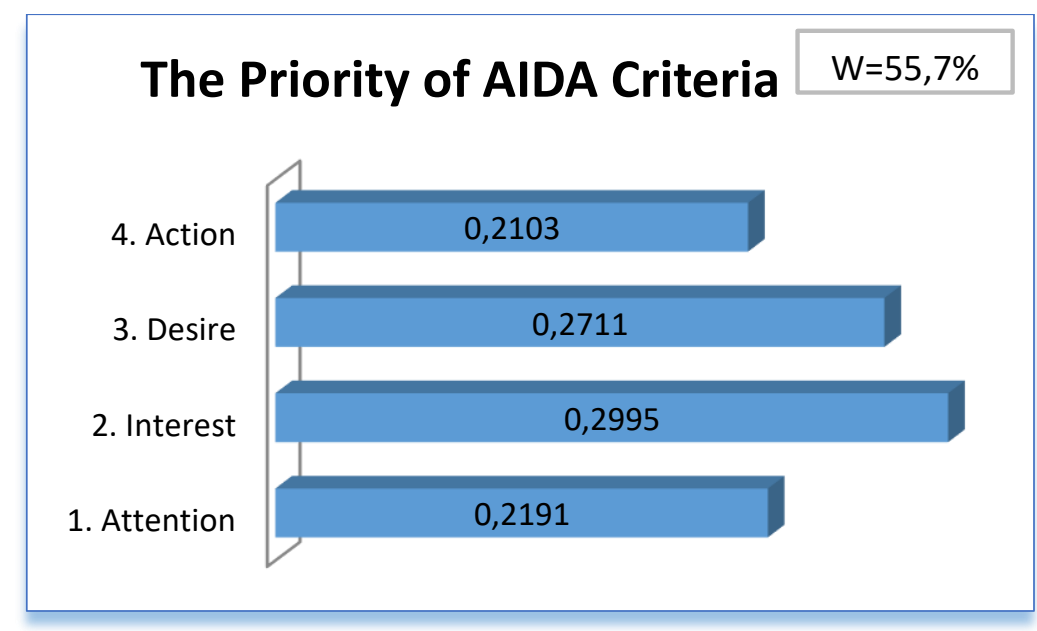

Graph 1. The Priority of AIDA Criteria

Source: Informants, data processed (2019)

The selection of Interest criteria as the top of priority according to the informants and the results of data processing, indeed, has a very strong reason, especially if it is related to the context of the current situation and conditions in which the community (as prospective customers of Islamic banking) actually has already aware and knows about the existence of financial products and services from the Islamic banking. But, generally they do not yet have sufficient knowledge (literacy) about product features, advantages and benefits of the product, and how to use and utilize Islamic banking financial products and services (in this case becoming Islamic banking customers). This condition is strengthened by the results of a financial literacy and inclusion survey conducted by OJK in 2016 which showed that the level of literacy (understanding) and the level of inclusion (utilization) of the public regarding Islamic banking products and services is still low. The Islamic banking literacy index in general only reached $6.69 \%$, while the Islamic banking inclusion index reached $9.61 \%$ [3]. This lack of knowledge and understanding has led to a lack of public interest and community decision to use Islamic banking financial products and services, supported and align with some previous studies conducted by Sardiana [21], Sardiana [22], and Handida and Sholeh [20]. They stated that the level of public literacy on Islamic finance significantly influences people's preferences to use Islamic banking products and services.

There is a theory named Hierarchy of Effect (HOE) that arranges a series of consumer steps when making a purchase decision towards a product or service. The HOE theory refers to the stage where consumers feel, process, and use information that comes from advertising and promotional media and other marketing communications. These stages are: cognitively (thinking), effectively (feeling), and conatively (action) [35]. This means that consumers in making a purchase of a product or service, firstly they reaches the stage of awareness (Attention) and knowledge of a product (Interest), then develops positive or negative feelings about the product (decision) which ultimately takes action to purchase and use or reject, and avoid the product (Action) [36]. The AIDA model (Strong, 1925) is one of the popular models derived from the HOE theory, and is an acronym for Attention, Interest, Desire and Action which regulates the cognitive processes of consumers when receiving information about a product to make a purchase [37]. This model is generally used as analytical aid in marketing to encourage 
action by stimulating consumers to purchase certain products or services. This is an effective way for advertisers to create an efficient promotional campaign by influencing consumers through four psychological stages, changing it from an unconscious condition to a real acquisition action, namely the purchase or use of services [38], [39].

Digital marketing provides an important 'bridge' to the relationship between customer perspectives that often touch or interact with the digital world by using digital conversation interfaces that are used by companies to provide relevant content for customers [6], and utilizing various digital media to create digital relationships with customers. This digital relationship will also strengthen customer engagement [40], [41]. Therefore, in the current digital era, digital marketing can play a role in increasing the literacy and inclusion of Islamic financial products and services, through the implementation of relevant techniques and strategies.

Based on the results of the evaluation and ranking carried out from the Delphi Phase-I and Phase-II through a consensus of experts and practitioners of digital marketing, nine alternative "digital marketing roles" were found. They are subsequently forming a basis for developing the network model in the ANP method. These results are then transformed into a network model in the Analytic Network Process (ANP) method using Super Decission software. The ANP network model and construction on the Super Decission software is the basis of data analysis in this study.

The output from Super Decisions software shows that the main role of digital marketing in the term of increasing literacy and inclusion of Islamic banking products or services is building the trust. These results can be seen in Graph 2. In relation to the business world in the digital era, building the trust is done by building company integrity by means of developing and maximizing digital assets in the form of interactive and responsive websites, fanpages, YouTube channels and official social media accounts, as well as creating useful promotional content. Building trust can be a determining factor in building customer loyalty, because customer loyalty to a brand (brand loyalty) is the main thing that must be a focus on the banking service business [25].

According to Rusydiana (2016), one of the main problems faced by Islamic banking in Indonesia is because the trust and public interest towards Islamic banks tends to be low. Lack of community interest in saving funds or becoming a customer of Islamic bank is due to distrust towards the Islamic bank institutions [42]. Trust, according to Hunt and Morgan (1994) is the center of all interrelationship between human beings (relational exchange) [43]. This is consistent with the opinion of our informant, Mr. Pikukuh Tutuko, one of the most famous digital marketing expert and practitioner in Indonesia, who states that:

"In the banking world, it is closely related to business transactions, and in those transactions a higher trust is required. To build trust is not easy, it requires focus and consistency to guarantee and provide a sense of security to people who want to become customers of an Islamic bank"

Trust arises when one party is willing to establish a relationship with another party that is trustworthy and honest, and trust arises if the trustee shows their quality which, according to Mayer, Davis and Schoorman (1995), states that the trustee must have the ability, benevolence, and integrity [44]. Solomon (2000) was describing a trust from alternative view which focusing on trusting as ongoing social practice. He stated that the trust does not flow from a trustor to a trustee; rather, it emerges from their interaction over time [45]. So that, to build a trust towards the Islamic banking industry, in the perspective of the digital ecosystem, can be started by building authentic and credible digital assets, as well as providing informative, communicative 
and interactive service systems to the customers. By building authentic and trusted digital asset, such as official website, Youtube channel, and an interactive, informative and communicative social media channels will increase customer engagement and customer loyalty towards Islamic banking product and service brands [41]. Furthermore, according to Kelton, Fleischmann and Wallace (2008), the Islamic banking institution as an information producer could also display their ratings as a means to promote trust in every information and promotional message they published [46].

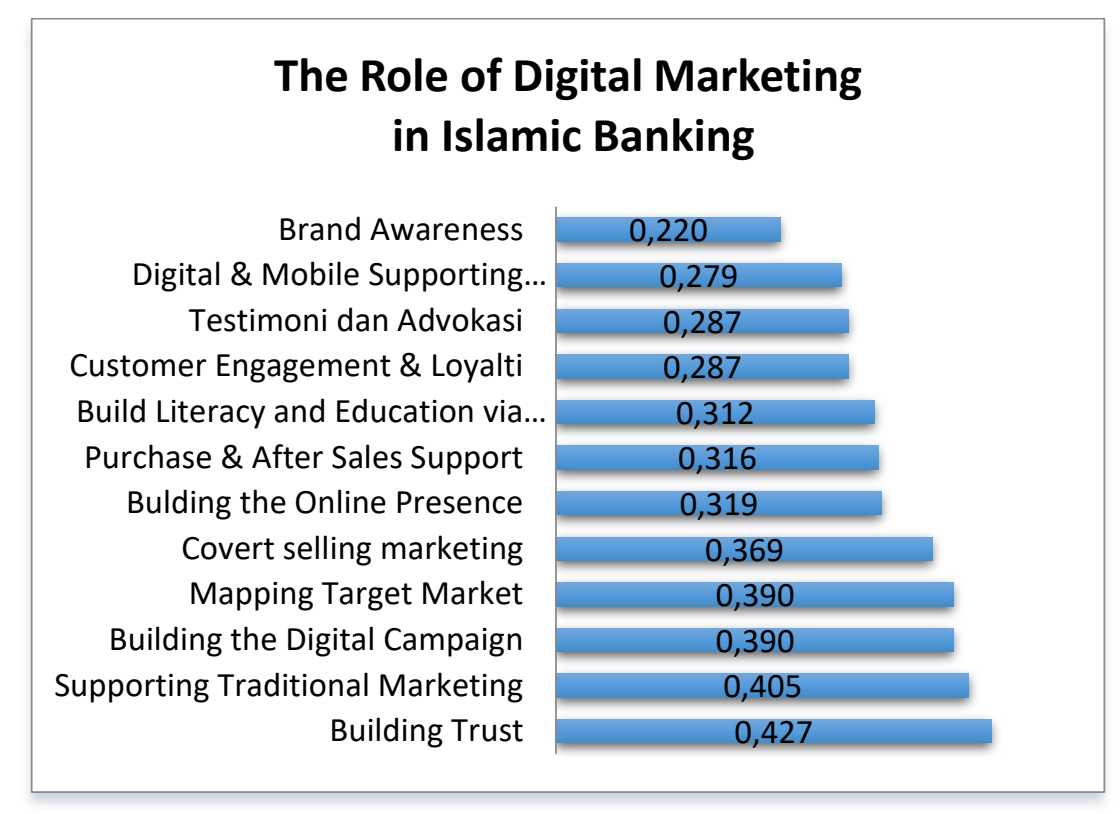

Graph 2. The Role of Digital Marketing in Islamic Banking Source: Informants, data processed (2019)

According to the result shown in Graph 2, the second role of digital marketing is supporting the traditional marketing, especially in the efforts to disseminate content through digital media in the form of new product information, promotional messages, education, discount information, electronic coupons and other benefits. Digital marketing can also be integrated with traditional marketing techniques in order to produce an integrated marketing system [47]. A study conducted by Zenith Optimedia (2015) shows that in the last five years the use of the internet is growing and developing, while on the other hand the use of other traditional media has declined or experienced a slight growth. From the research data, Internet media users increased by $105 \%$, outdoor media increased by $3 \%$. While television media decreased by $8 \%$, radio media decreased by $15 \%$, magazines decreased by $23 \%$, and newspapers experienced the biggest decline, amounting to $31 \%$ [48].

The same study conducted by Zenith Optimedia (2015) revealed that the average person spends more than 490 minutes each day using several types of media, but what is surprising is that television media continues to dominate, with an average time of around 3 hours per day while internet usage is in second place [48]. This fact shows that there is a decrease in the use of television media, while the use of internet media continues to grow [47]. Meanwhile, a recent 
study by Zenith Optimedia (2018) shows that since the beginning of the emergence of the internet in the mid-1990s, advertising through internet media (both desktop and mobile) has continued to increase and has resulted in a decline in print media advertising. Over the past ten years advertising on the internet has increased from $9 \%$ of total global advertising spending (in 2007) to $38 \%$ (in 2017). Meanwhile, the portion of global advertising spending in print media (newspapers) has fallen from $27 \%$ to $10 \%$, advertising in magazines' has dropped from $12 \%$ to $5 \%$. Print media will continue to lose market share because readers continue to switch to the online version, or other forms of information and entertainment as a whole. It is estimated, newspapers and magazines will continue to shrink at an average rate of 5\% and $6 \%$ per year, and will end with $7 \%$ and $4 \%$ market share respectively by 2020 [49].

Those previous studies illustrate that although the use of internet media for advertising continues to increase significantly, a small portion of the public still uses traditional media, so that traditional marketing will still continue to exist for the next few years. For this reason, integration between digital marketing methods and traditional marketing is needed, specifically in marketing some products or services to the wider community. This is supported by research conducted by Todor (2016) which suggests an integration between traditional marketing and digital marketing. The combination of the two marketing approaches, namely traditional marketing and digital marketing can provide the best solution for the company when it is trying to increase visibility in the market, as well as to increase brand awareness [47].

The integration between traditional and digital marketing, in the term of marketing the Islamic banking products and services, is also in line with our informants, Mr. Andi Dwi Riyanto, from digital marketing academic and trainer (nickname: Andi Kroya), who states that:

"Digital marketing is one of the efforts to digitalize the marketing sector, or adopting digital technology and utilizing digital media into marketing approach because currently we are facing the digital era. So the role and function of digital marketing is clear. Must be able to help, at least is to help the sector or unit or marketing division itself, which commonly still rely on traditional marketing"

The third role of digital marketing is building digital campaign and mapping the target market. Both of these roles get almost the same priority weight, and both have the same important role. The role of digital marketing in building digital campaigns is closely related to efforts to build literacy towards Islamic banking product or service campaigns on digital media such as websites, Facebook, Instagram, Twitter, and Youtube, as well as other digital media. In order to increase public literacy towards Islamic banking financial products and services, digital marketing plays a role in building digital campaigns which focuses on raising awareness specifically on a large scale, and focusing on efforts to explain features and benefits, and eliminate perceptions of complexity and uncertainty. This current result is aligned with our informants, Mr. Dhoni Rakawira, who is currently the CEO of Digital Media Labs (DMLabs). He states that:

"To increase literacy towards Islamic banking products and services, it can be utilized in terms of content. More specifically is to raise the content that is correlated with the product they will delivered to the target market and wrapped into an attractive digital campaign"

According to Wilson et al. (2013), who stated that the central component of every good marketing is concerning into individual and group identities [50]. By mapping and classifying 
the targeted customer based on their profile and demographics (age, sex, occupation, domicile, preference and so on), marketing can be more focused and efficient. Digital marketing can also plays a role in mapping the target market. Mapping the target market is an effort to get potential prospective customer. Those can be done through the utilization of searching features, Google Analytics, and other features available on the internet and social media. Google Analytics, is a tool or a system used to analyze and measure data from websites with the objective of grabbing some informations about customer insights (keywords, average access time, devices used) and customer behavior. This insights are used by marketers in customizing and delivering suitable and specific promotional messages and contents about products and services to the specific and targeted customers. The efforts will effectively supporting the marketing strategy of a company to increase and enlarge the market share.

\section{Conclusion}

\subsection{Overview}

Based on the results obtained in the research and discussion above, we conclude that there are some roles of digital marketing to enlarge the Islamic banking financial product and services market share. The main role of digital marketing in the terms of increasing literacy and inclusion towards Islamic banking products and services is the effort to build public trust by developing a credible, interactive and informative digital assets (websites, social media accounts, fanpages, YouTube channels, and digital channels others). The second is supporting the traditional marketing. And the third is building and developing digital campaigns for Islamic financial products and services through digital media in the form of promotional messages such as text content, messages, figures, and videos. Those promotional messages must be specified and tailored to the profile, demographics and needs of prospective customers through the target market mapping.

\subsection{Managerial and Academics Implication}

This research can be used as a reference and direction for further research, especially research related to digital marketing strategies. The influence of digital marketing towards public interests and decisions to purchase or to use Islamic banking financial products and services is very significant. Through this research, we found the possibility of encouraging for further research about the influence of digital marketing channels (mobile smartphones, social media marketing, websites, etc.) on customer behavior, interests and decisions of the public or prospective customers in buying, using and utilizing other Islamic financial services such as: Islamic insurance, Islamic capital markets, Islamic financing and sukuk. Theoretically, this research contributes to the field of marketing, particularly those related to the promotion and literacy of Islamic financial products and services. As digital technology develops very rapidly, a revolutionary promotional approaches and strategies are needed. By maintaining the integrity, credibility and accountability of the company within the digital ecosystems could increase public trust towards Islamic banking. 


\section{References}

[1] Sultan, Ralph and Schoeffler, Sidney: Profit Impact of Market Strategy in Advertising Research Foundation Proceedings, 18th Conference, New York: Advertising Research Foundation (1972)

[2] Schoeffler, Sidney; Buzzell, Robert D. and Heany, Donald F: Impact of Strategic Planning on Profit Performance. Harvard Business Review, Vol. 52, pp. 137-145 (1974)

[3] Otoritas Jasa Keuangan: Roadmap Pengembangan Keuangan Syariah Indonesia 2017 - 2019 (2017)

[4] Otoritas Jasa Keuangan: Snapshot Perbankan Syariah Indonesia tahun 2018 (2018)

[5] Ahmad, N., \& Haron, S: Perceptions of Malaysian corporate customers towards Islamic banking products and services. International Journal of Islamic Financial Services, 3(4), pp.13-29 (2002)

[6] Wymbs, C.: Digital marketing: The Time for a New “Academic Major” Has Arrived. Journal of Marketing Education, 33(1), pp. 93-106 (2011)

[7] Chaffey, D., \& Ellis-Chadwick, F.: Digital Marketing, strategy, implementation and practice. 6 uppl (2016)

[8] WSI: Digital Minds: 12 Things Every Business Needs to Know about Digital marketing. Victoria: Friesen Press, pp. 7 (2013)

[9] Alkhateeb, F. M., Clauson, K. A., Khanfar, N. M., \& Latif, D. A.: Legal and regulatory risk associated with Web 2.0 adoption by pharmaceutical companies. Journal of Medical Marketing, 8(4), 311-318 (2008)

[10]Kierzkowski, A., McQuade, S., Waitman, R., \& Zeisser, M.: Current research: marketing to the digital consumer. The mckinsey quarterly, (2), pp.180-183 (1996)

[11]Wertime, K., \& Fenwick, I.: DigiMarketing: The essential guide to new media and digital marketing. John Wiley \& Sons (2011)

[12] Stephen, A. T.: The role of digital and social media marketing in consumer behavior. Current Opinion in Psychology, Vol. 10, pp. 17-21 (2016)

[13]Patrutiu-Baltes, L.: Inbound Marketing-the most important digital marketing strategy. Bulletin of the Transilvania University of Brasov. Economic Sciences. Series V, 9(2), pp.61 (2016)

[14]Simmons, M.: What's in store for 2013? digital marketing's role in lead generation. Agency Sales, 43(7), pp. 48-50 (2013)

[15]Piñeiro-Otero, T., \& Martínez-Rolán, X.: Understanding Digital marketing-Basics and Actions. In $M B A$ (pp. 37-74). Springer, Cham (2016)

[16]Rogers, E. M.: Diffusion of Innovations: modifications of a model for telecommunications. In Die diffusion von innovationen in der telekommunikation (pp. 25-38). Springer, Berlin, Heidelberg (1995) [17]Wunderlich, P., Größler, A., Zimmermann, N., \& Vennix, J. A.: Managerial influence on the diffusion of innovations within intra-organizational networks. System Dynamics Review, 30(3), pp. 161185 (2014)

[18]Frattini, F., Bianchi, M., Massis, A., \& Sikimic, U.: The role of early adopters in the diffusion of new products: Differences between platform and non-platform innovations. Journal of Product Innovation Management, 31(3), pp. 466-488 (2014)

[19]Kung, L.: Strategic Management in the Media: theory to practice. London: Sage (2008)

[20]Handida, R. D., \& Sholeh, M.: Pengaruh Tingkat Pengetahuan, Kualitas Layanan, dan Tingkat Literasi Keuangan Syariah terhadap Pengambilan Keputusan Masyarakat Muslim Menggunakan Produk Perbankan Syariah di Daerah Istimewa Yogyakarta. Jurnal Ekonomi dan Pendidikan, 15(2), pp. 84-90 (2018)

[21]Sardiana, A.: The Impact of Literacy to Islamich Financial Service Preferences. Etikonomi, 15(1), pp. 43-62 (2016)

[22]Sardiana, A.: Preferensi Penggunaan Jasa Keuangan Syariah Berdasarkan Literasi Keuangan Syariah. In Proceeding Seminar Nasional hasil Penelitian,Vol. 1 No. 1, pp. 41-52 (2018)

[23]Hakim, S. A., Bhatti, O. K., \& Al-Jubari, I. (2011). Advertising of Islamic banking products. Annals of Management Research, 1(2), 60-70 (2011)

[24]Davis, J.: Brands Struggle to Deliver Personalised Digital Expereinces, Digital Marketing Magazine (2017)

[25]Mayilvaganan, S., \& Karthikeyan, G.: Marketing of banking services. International Journal of Marketing and Technology, 2(11), pp. 134 (2012)

[26]Gironda, J. T., \& Korgaonkar, P. K.: Understanding consumers' social networking site usage. Journal of Marketing Management, 30(5-6), pp. 571-605 (2014) 
[27]Michaelson, D., \& Stacks, D. W.: Standardization in public relations measurement and evaluation. Public Relations Journal, 5(2), pp. 1-22 (2011)

[28]Ngeru, J. N., Bardhan, T. K., \& Pitts Jr, R. A.: Selection of an Ideal Enterprise Integration Approach using Delphi-ANP Approach. Journal of Management \& Engineering Integration, 4(1), pp. 99 (2011) [29]Dalkey, N. \& Helmer, O.: An Experimental Application of the Delphi Method to the use of experts. Management Science, 9(3), pp.458-467 (1963)

[30]Spencer-Cooke, B.: Conditions of Participation in Rural, Non-Formal Education Programmes: A Delphi Study. Educational Media International, 26(2), pp. 115-124 (1989)

[31]Saaty, T. L., \& Vargas, L. G.: Decision making with the analytic network process (Vol. 282). Springer Science+ Business Media, LLC (2006)

[32] Saaty, T. L.: Analytic network process (pp. 64-72). Springer US (2013)

[33] APJII, P.: Perilaku Pengguna Internet Indonesia. Asosiasi Penyelenggara Jasa Internet Indonesia, Survei (2017)

[34]Bayo-Moriones, A., \& Lera-Lo'pez, F.: A firm-level analysis of determinants of ICT adoption in Spain. Technovation, 27(6/7), pp. $352-366$ (2007)

[35]Barry, T. E., \& Howard, D. J.: A review and critique of the hierarchy of effects in advertising. International Journal of Advertising, 9(2), pp. 121-135 (1990)

[36]Kotler, P. and Bliemel, F.: Marketing-management: Analyse, Planung und Verwirklichung, Schaeffer-Poeschel, Stuttgart (2001)

[37]Strong, E. K.: The psychology of selling and advertising. McGraw-Hill book Company, Incorporated (1925)

[38]Lee, S. H., \& Hoffman, K. D.: Learning the ShamWow: Creating infomercials to teach the AIDA model. Marketing Education Review, 25(1), pp. 9-14 (2015)

[39] Ghirvu, A. I.: The AIDA model for advergames. The USV Annals of Economics and Public Administration, 13(1 (17)), pp. 90-98 (2013)

[40]Tiago, M. T. P. M. B., \& Veríssimo, J. M. C.: Digital marketing and social media: Why bother?. Business Horizons, 57(6), pp. 703-708 (2014)

[41]Kotler, P., Kartajaya, H., \& Setiawan, I.: Marketing 4.0: Moving from traditional to digital. John Wiley \& Sons (2016)

[42]Rusydiana, A. S.: Analisis masalah pengembangan perbankan syariah di Indonesia: Aplikasi metode Analytic Network Process. Esensi: Jurnal Bisnis dan Manajemen, 6(2), pp. 237-246 (2016)

[43]Morgan, R. M., \& Hunt, S. D.: The commitment-trust theory of relationship marketing. Journal of marketing, 58(3), pp. 20-38 (1994)

[44]Mayer, R. C., Davis, J. H., \& Schoorman, F. D.: An integrative model of organizational trust. Academy of management review, 20(3), pp. $709-734$ (1995)

[45]Solomon, R. C.: Trusting. In M. Wrathall \& J. Malpas (Eds.), Heidegger, coping, and cognitive science: Essays in honor of Hubert L. Dreyfus (Vol. 2, pp. 229-244). Cambridge, MA: The MIT Press (2000)

[46] Kelton, K., Fleischmann, K. R., \& Wallace, W. A.: Trust in digital information. Journal of the American Society for Information Science and Technology, 59(3), pp. 363-374 (2008)

[47]Todor, R. D.: Blending traditional and digital marketing. Bulletin of the Transilvania University of Brasov. Economic Sciences. Series V, 9(1), pp. 51 (2016)

[48]ZenithOptimedia.: Advertising expenditure forecasts march 2015 (2015)

[49]ZenithOptimedia.: Advertising expenditure forecasts march 2018 (2018)

[50]Wilson, J. A., Belk, R. W., Bamossy, G. J., Sandikci, Ö., Kartajaya, H., Sobh, R., ... \& Scott, L.: Crescent marketing, Muslim geographies and brand Islam. Journal of Islamic Marketing (2013) 